\title{
Untold Stories of Goldman v. Weinberger: Religious Freedom Confronts Military Uniformity
}

Samuel J. Levine

Touro Law Center

Follow this and additional works at: https://digitalcommons.tourolaw.edu/scholarlyworks

Part of the Constitutional Law Commons

\section{Recommended Citation}

60 A.F.L. Rev. 205 (2010)

This Article is brought to you for free and open access by the Faculty Scholarship at Digital Commons @ Touro Law Center. It has been accepted for inclusion in Scholarly Works by an authorized administrator of Digital Commons @ Touro Law Center. For more information, please contact Iross@tourolaw.edu. 


\title{
UNTOLD STORIES OF GOLDMAN V. WEINBERGER: RELIGIOUS FREEDOM CONFRONTS MILITARY UNIFORMITY
}

\author{
SAMUEL J. LEVINE*
}

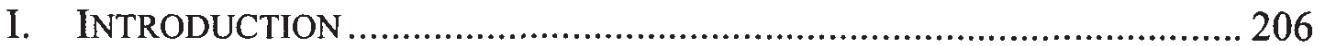

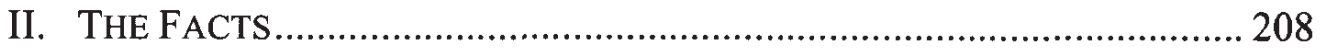

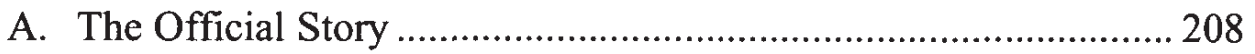

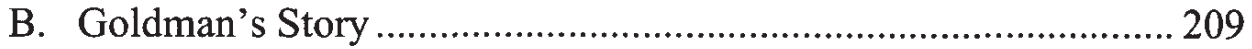

1. Goldman's Prior Military Service ........................................... 209

2. The Origins of the Dispute ................................................... 210

3. Other Aspects of the Air Force's Conduct ................................ 212

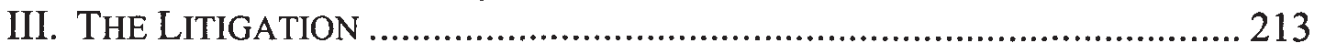

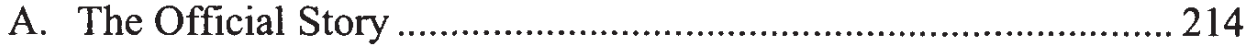

1. The District Court ................................................................. 214

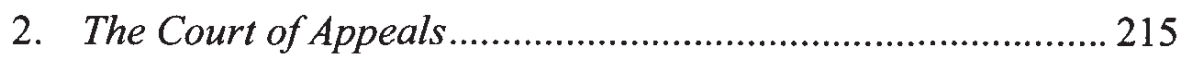

3. The Supreme Court ............................................................ 217

B. The Unofficial Story …............................................................. 220

1. Perspectives of Judge Robinson and Judge Starr .................220

2. The Government's Strategy................................................... 221

IV. Conclusion: Looking Back at the CASE - Questions That Remain .... 223

\footnotetext{
* Professor of Law \& Director, Jewish Law Institute, Touro Law Center. LL.M., Columbia University, 1996; J.D., Fordham University, 1994; B.A., Yeshiva University, 1990; Ordination, Yeshiva University, 1996.

An earlier version of this article was published as a chapter in LAW AND RELIGION: CASES IN CONTEXT (Leslie Griffin ed., Aspen Publishers 2010). It is printed here with permission of the publisher. I thank Leslie Griffin for soliciting this chapter, Simcha Goldman,Ron Rakowsky, Jim Cohen, Ken Starr, Nat Lewin, Steve Solarz, and Rabbi Yitzchak Adlerstein for discussions of the case, and Scott Hodges for helpful suggestions. I thank Fraida Liba, Yehudah, Aryeh, Rachel, and Shira for continued encouragement.
} 


\section{INTRODUCTION}

The U.S. Supreme Court has historically shown considerable deference to the military on matters of good order and discipline. ${ }^{1}$ A significant part of good order and discipline in the military relies on uniformity-uniformity in physical standards, uniformity in decorum, uniformity in clothing. At the same time, however, the Court has emphasized that "members of the military are not excluded from the protection granted by the First Amendment." ${ }^{\text {A }}$ As illustrated by current events, conflicts may arise between the military's legitimate interest in uniformity and individuals' constitutionally protected right to the free exercise of religion. Facing a dramatic shortage in manpower, the U.S. Army recently decided to relax uniform rules to accommodate the religious dress requirements for adherents of the Sikh religion. The exceptions to the regulations include allowing Sikhs to wear otherwise unauthorized headgear-a turban - and to wear otherwise unauthorized beards. ${ }^{3}$

Reflection upon these events may lead to questions about the extent to which these accommodations to religious garb will impact future policy decisions, at times when the United States military is not facing recruiting and retention difficulties. Although federal law and Department of Defense (DOD) policy require the military services to accommodate religious practice, there may be compelling reasons to restrict soldiers from wearing beards, such as the inability for a gas mask to seal against the facial hair. In addition, some have argued that turbans impact good order and discipline because they diminish the ability to distinguish officers from enlisted personnel, ${ }^{4}$ while others have voiced concern over perceptions of favoritism or inequity that may result from substantial deviations from uniform standards. In short, having accommodated these exceptions to uniform standards for religious practice, can the Army continue to maintain

\footnotetext{
${ }^{1}$ See, e.g., Rostker v. Goldberg, 453 U.S. 57, 70 (1981) (stating that judicial deference "is at its apogee when legislative action under the congressional authority to raise and support armies and make rules and regulations for their governance is challenged"); Brown v. Glines, 444 U.S. 348, 354 (1980) ("To ensure that they always are capable of performing their mission promptly and reliably, the military services must insist upon a respect for duty and discipline without counterpart in civilian life."); Burns v. Wilson, 346 U.S. 137, 140 (1953) (stating that "the rights of men in the armed forces must perforce be conditioned to meet certain overriding demands of discipline and duty, and the civil courts are not the agencies which must determine the precise balance to be struck in this adjustment.").

${ }^{2}$ Parker v. Levy, 417 U.S. 733, 758 (1974).

3 See Steve Elliot, Sikh Soldiers Allowed to Serve, Retain Their Articles of Faith, http://www.army.mil/-news/2010/03/25/36339-sikh-soldiers-allowed-to-serve-retain-theirarticles-of-faith/; Paul Steven Ghiringhelli, Traditional Sikh Serves as Army Dentist on Fort Drum, http://www.army.mil/-news/2010/05/20/39536-traditional-sikh-serves-as-armydentist-on-fort-drum/; Ist Sikh in Decades Graduates Army Officer School, http://www.usatoday.com/news/religion/2010-03-22-sikh-army_N.htm.

${ }^{4}$ Officers typically display their distinctive rank insignia on their headgear, a practice that may not be possible when turbans are worn.
} 
arguments asserting a substantial or compelling interest in uniformity? The inevitable tension surrounding this issue brings to mind the most famous constitutional case to originate in the Air Force, the 1986 U.S. Supreme Court case of Goldman v. Weinberger. ${ }^{5}$

On March 25, 1986, the Court handed down a 5-4 decision ruling that Air Force regulations prohibiting Simcha Goldman from wearing a yarmulke while in uniform did not violate Goldman's First Amendment right to the free exercise of religion. ${ }^{6}$ The Court's majority opinion, which accepted the government's assertion that allowing Goldman to wear a yarmulke would unduly upset important military interests, drew unusually harsh responses from both dissenting justices and legal scholars. For example, in a stinging dissenting opinion, Justice William Brennan characterized the majority's position as no less than an "eva[sion of] its responsibility" and an "abdicat[ion of] its role as principal expositor of the Constitution and protector of individual liberties in favor of credulous deference to unsupported assertion of military necessity."

Scholarly reaction likewise offered little sympathy for the majority's approach. Kent Greenawalt, one of the leading church-state theorists in the country, described the majority opinion as "both surprising and wholly unsatisfying from an intellectual point of view." Writing in the Foreword to the Harvard Law Review, Frank Michelman referred to the Goldman decision as an illustration of "the discriminatory potential of determinedly abstract law,"10 comparable to the Court's infamous holding in Plessy v. Ferguson, ${ }^{11}$ which relied upon "sedulous abstraction from concrete experience" to conclude that "separate" could have seemed "equal." 2

On the basis of interviews, unpublished documents, and press reports, this article suggests that, upon closer examination, perhaps what stands out most about the events surrounding the Goldman decision is the untold story of the process, which differs in significant respects from the official version of both the facts of the case and the ensuing litigation. The official narrative presents a dispute between a Jewish Airman who wants to wear his yarmulke during work and a commanding officer demanding strict adherence to military uniform protocol. However, as this article relates, the unofficial narrative demonstrates how much of the process was driven by more subtle factors that played a central role at each stage of the case.

\footnotetext{
${ }^{5} 475$ U.S. 503 (1986).

${ }^{6}$ Goldman v. Weinberger, 475 U.S. 503 (1986).

${ }^{7}$ Id. at 515 (Brennan, J., dissenting).

${ }^{8} I d$. at 514 (Brennan, J., dissenting).

${ }^{9}$ Kent Greenawalt, Religion and the Rehnquist Court, 99 Nw. U. L. REv. 145, 148 (2004).

10 Frank I. Michelman, The Supreme Court, 1985 Term-Foreword: Traces of Self-

Government, 100 HARV. L. REV. 4, 31 (1986).

${ }^{11} 163$ U.S. 537 (1896).

${ }^{12}$ Michelman, supra note 5, at 31.
} 


\section{THE FACTS}

\section{A. The Official Story}

As noted in the court opinions, for many years prior to the litigation, Goldman served in the military in a variety of capacities, wearing his yarmulke while in uniform without incident. ${ }^{13}$ As an ordained rabbi who observed Orthodox Jewish religious practice, Goldman thereby complied with the religious obligation to keep his head covered at all times. ${ }^{14}$ Goldman's military career began with service as a chaplain in the United States Navy from 1970 to $1972 .^{15}$ In 1977, after completing a Ph.D. in clinical psychology through a military scholarship program, Goldman joined the Air Force as a captain, serving as a clinical psychologist at the Mental Health Clinic of the March Air Force Base Regional Hospital in Riverside, California. $^{16}$ Throughout several years of service, Goldman covered his head with his service cap when outdoors and continued to wear his yarmulke indoors without raising any concerns. ${ }^{17}$ In fact, Goldman received consistently outstanding evaluations from his superiors, including the category "Professional qualities (Attitude, dress, cooperation, bearing)."

However, on May 8, 1981, Goldman was called before Colonel Joseph Gregory, the hospital commander at the installation, who informed Goldman that wearing a yarmulke while on duty violated Air Force rules regulating headgear. ${ }^{19}$ Colonel Gregory ordered Goldman not to wear his yarmulke outside the hospital, and he later amended the order to prohibit Goldman from wearing his yarmulke inside the hospital as well. ${ }^{20}$ Colonel Gregory's orders were prompted by a complaint filed by a military lawyer who had cross-examined Goldman in a court-martial proceeding in which Goldman wore his yarmulke. ${ }^{21}$ When Goldman refused to comply with the orders, he received a letter of reprimand and was informed that he could face a court-martial. ${ }^{22}$ In addition, Colonel Gregory, who had previously recommended approval of Goldman's application for extension of active service, instead submitted a negative recommendation. ${ }^{23}$ Goldman filed suit on the grounds that the orders violated his First Amendment rights to free exercise of religion. $^{24}$

\footnotetext{
${ }^{13}$ Goldman v. Sec'y of Def., 734 F.2d 1531, 1532-33 (D.C. Cir. 1984).

${ }^{14}$ Id. at 1532.

${ }^{15}$ Id.

${ }^{16} I d$. at $1532-33$.

${ }^{17} \mathrm{Id}$. at 1533 .

${ }^{18} I d$.

${ }^{19} I d$.

${ }^{20} \mathrm{Id}$.

${ }^{21}$ See Goldman v. Weinberger, 475 U.S. 503, 505 (1986).

${ }^{22} \mathrm{Id}$.

${ }^{23} \mathrm{Id}$.

${ }^{24}$ Id. at 506.
} 


\section{B. Goldman's Story}

\section{Goldman's Prior Military Service}

Although the Court of Appeals and the Supreme Court acknowledged that Goldman had worn his yarmulke for many years of service without incident, ${ }^{25}$ the opinions did not tell the entire story. For example, during Goldman's years as a chaplain in the Navy, he was stationed at the Marine Corps Recruit Depot, Parris Island, South Carolina. ${ }^{26}$ The senior chaplain informed Goldman that Goldman's commander had called and asked, "Who is the hippie walking around my command with the beanie on his head?" The chaplain explained that Goldman was a "Jewish rabbi" and that the head covering was "his way of telling God that he's on duty." The commander was satisfied with this explanation, responding, "Okay, just make sure he keeps his brass polished!"27

In fact, Goldman remained with the Marines for two years, and in this most disciplined of military environments, he never experienced any other expressions of concern about his yarmulke. ${ }^{28}$ In addition, during these years, Goldman was photographed in uniform and wearing his yarmulke standing alongside the Secretary of the Defense, Melvin Laird. Goldman, Secretary Laird, and two other individuals pictured with them, including the major general commanding the base, are all smiling broadly at the photographer or at one another. ${ }^{29}$ Thus, Goldman did not hesitate to wear his yarmulke in uniform when he reported for duty with the Air Force in 1977, and for more than three years at March Air Force Base Goldman continued to serve with distinction without receiving any negative attention because of his yarmulke. ${ }^{30}$

Given that for so many years neither the Marine Corps commanders on Parris Island, nor the Secretary of Defense, nor the commanders at March Air Force Base considered Goldman's yarmulke to be a threat to discipline or uniformity, it seems surprising that in 1981, the hospital commander suddenly raised such voluble concerns about Goldman's wearing a yarmulke. Likewise, it seems difficult to understand why the United States Government considered the matter so important that it litigated the case all the way to the United States Supreme Court. As in countless historical events, the answers to these basic questions may be found in the mundane,

\footnotetext{
${ }^{25}$ See id. at 505; Goldman v. Sec'y of Def., 734 F.2d 1531, 1532-33 (D.C. Cir. 1984).

26 Author's Interview with Simcha Goldman, Los Angeles, California, May 4, 2008 [hereinafter Goldman Interview].

${ }^{27}$ Id.

${ }^{28}$ Id.

${ }^{29} I d$. (photograph on file with author).

${ }^{30} \mathrm{Id}$.
} 
personal-and sometimes petty-decisions and responses of certain individuals who played crucial roles in the story.

\section{The Origins of the Dispute}

As the Supreme Court's majority opinion noted in passing, the dispute over Goldman's yarmulke began in April 1981, after Goldman wore his yarmulke while testifying as a defense witness at a court-martial. ${ }^{31}$ In a concurring opinion, Justice Stevens suggested that the timing of the complaint against Goldman gave the Court "reason to believe that the policy of strict enforcement against Captain Goldman had a retaliatory motive.,"32 Again, however, although the justices identified an important piece of the puzzle that gave rise to the Goldman case, the Court did not describe the whole story connecting Goldman's testimony to the subsequent complaint about his yarmulke.

This piece of the story actually began at another court martial in 1980 , a year before the event mentioned by the Supreme Court. At the earlier proceeding, Goldman testified as a defense witness, providing a psychological evaluation of the defendant. ${ }^{33}$ Goldman was cross-examined by the military prosecutor, Captain Bouchard. ${ }^{34}$ In the course of the crossexamination, Bouchard asked whether Goldman had conducted psychological testing on the defendant. ${ }^{35}$ When Goldman responded that he had used the Minnesota Multiphase Personality Inventory (MMPI), Bouchard asked questions that were critical of the MMPI. ${ }^{36}$ Throughout his testimony, Goldman was dressed in his uniform and wore his yarmulke, without eliciting any protests or objections from Bouchard, the judges, or any of the other officers present at the hearing. ${ }^{37}$

One year later, Goldman testified as a defense witness in the case referenced by the Supreme Court. ${ }^{38}$ Once again, Goldman wore both his uniform and his yarmulke and was questioned by the same prosecutor. ${ }^{39}$ Goldman explained that in this case, he had not found it necessary to conduct psychological testing. ${ }^{40}$ Bouchard then asked a question critical of Goldman's decision not to use the MMPI, upsetting Goldman, who recalled that in the earlier proceeding, Bouchard had devalued the MMPI. ${ }^{41}$ From Goldman's perspective, Bouchard was employing an intellectually dishonest

31 See Goldman v. Weinberger, 475 U.S. 503, 505 (1986).

${ }^{32} \mathrm{Id}$. at 511 (Stevens, J., concurring).

${ }^{33}$ Goldman Interview, supra note 26.

${ }^{34} I d$.

${ }^{35} \mathrm{Id}$.

${ }^{36} \mathrm{Id}$.

${ }^{37} \mathrm{Id}$.

${ }^{38}$ See supra note 26-27 and accompanying text.

${ }^{39}$ Goldman Interview, supra note 26.

${ }^{40} \mathrm{Id}$.

${ }^{41}$ Id. 
strategy, adopting contradictory views of the MMPI, in each case aiming to raise doubts about Goldman's methods and credibility. ${ }^{42}$ Goldman responded with a vague answer, prompting a further exchange in which Goldman commented on the irrelevance of the question, thereby causing Bouchard both frustration and embarrassment. ${ }^{43}$ It was only after this second encounter that Bouchard filed a complaint objecting to Goldman's wearing of a yarmulke while in uniform during his testimony. ${ }^{44}$

Notably, other Air Force lawyers had different perspectives regarding Goldman's decision to wear his yarmulke while in uniform. For example, Captain James S. Cohen, the defense attorney who called Goldman as a mitigation witness in the 1981 court-martial, was not concerned by the fact that Goldman would testify while wearing a yarmulke. ${ }^{45}$ Cohen considered the yarmulke unobtrusive and, accordingly, he did not raise it as an issue in his conversations with Goldman. ${ }^{46}$ In fact, although Cohen was not involved in the later proceedings against Goldman, had he been asked to do so, he would have been willing to defend Goldman in the case. ${ }^{47}$

After the 1981 court-martial, Major Ronald J. Rakowsky, the senior law officer at the base, was consulted about whether it had been permissible for Goldman to wear his yarmulke in court. ${ }^{48}$ Rakowsky concluded, on the basis of his extensive knowledge, experience, and research on the subject, that the regulations did not provide an exception for wearing a yarmulke while in uniform. ${ }^{49}$ However, Rakowsky also recognized the important free exercise implications of the case, and he understood that Goldman was asserting strong and sincere religious beliefs. ${ }^{50}$ As Rakowsky explained to Colonel Charles McDonald, the Wing Commander, the conflicting constitutional interests of military authority and religious liberty represented an instance of "an irresistible force versus an immovable object." of the constitutional significance of the issue, Rakowsky strongly recommended that Goldman be issued a Letter of Reprimand, so that any ensuing litigation would be handled as a civil matter in United States District Court rather than treated as a criminal matter subject to military justice. ${ }^{52}$ McDonald accepted his recommendation, and the case proceeded in federal court. ${ }^{53}$

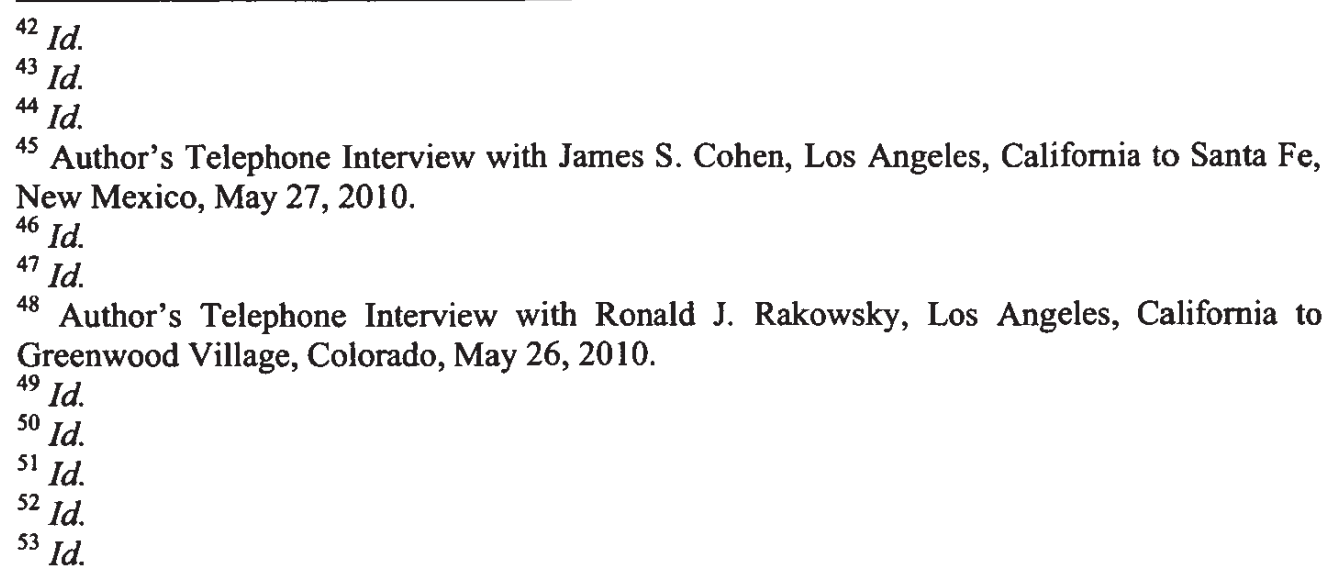




\section{Other Aspects of the Air Force's Conduct}

The official version of Goldman's story as depicted in the cases does not include the dubious process some of the Air Force officers undertook to ascertain the significance of the yarmulke to Goldman's religious faith. Colonel Gregory asked the base chaplain, a colonel who was not Jewish, to make an inquiry as to whether wearing a yarmulke constituted a religious obligation. ${ }^{54}$ Despite knowing that Goldman was a rabbi and had served as a Navy chaplain, the base chaplain decided to contact the New York-based Jewish Welfare Board, an organization that acted as the ecclesiastical liaison for the military regarding matters of Jewish faith. ${ }^{55}$ However, rather than speaking with a rabbi at the Jewish Welfare Board, the base chaplain spoke with Dr. Diana Coran, who, he claimed, informed him that wearing a yarmulke was not a religious obligation. ${ }^{56}$

Disturbingly, in the process of consulting with Dr. Coran, the commanders not only deferred to the purported position of an individual who was not a rabbi, but they either misunderstood or intentionally misstated Dr. Coran's response. ${ }^{57}$ As Dr. Coran later explained to Goldman, she had actually told the base chaplain that there is a Jewish religious obligation to cover one's head at all times, but that the form of head covering need not be a yarmulke; for example, the obligation can be fulfilled by wearing a cap. ${ }^{58}$ Of course, because Goldman could not wear his military cap while indoors, he could satisfy his religious obligation only by wearing an item that was not part of his uniform, such as a yarmulke. Thus, the commanders relied on their own distorted interpretation of a statement from an individual who was not a rabbi as a basis for denying Goldman, who was a rabbi, the right to exercise his religious obligation. ${ }^{59}$

${ }^{54}$ Goldman Interview, supra note 26.

${ }^{55} \mathrm{Id}$.

${ }^{56} I d$.

${ }^{57} \mathrm{Id}$.

${ }^{58}$ Id.

${ }^{59}$ Id. Beyond the disconcerting process employed by these officials, the Air Force's underlying assumption, that it had the authority to second-guess a religious adherent's portrayal of religious obligations, contradicts a fundamental tenet of Free Exercise law. See Thomas v. Review Bd. Ind. Employment Sec. Div., 450 U.S. 707 (1981); Richard W. Garnett, Assimilation, Toleration, and the State's Interest in the Development of Religious Doctrine, 51 UCLA L. REV. 1645 (2004); Jared A. Goldstein, Is There a "Religious Question" Doctrine? Judicial Authority to Examine Religious Practices and Beliefs, 54 CATH. U. L. Rev. 497, 497 (2005); Kent Greenawalt, Hands Off! Civil Court Involvement in Conflicts over Religious Property, 98 ColuM. L. Rev. 1843, 1844 (1998); Samuel J. Levine, Rethinking the Supreme Court's Hands-Off Approach to Questions of Religious Practice and Belief, 25 Fordham URB. L.J. 85 (1997); Symposium, The Supreme Court's Hands-Off Approach to Religious Doctrine, 84 Notre Dame L. Rev. 793(2009).

Nevertheless, throughout the litigation process, the government would repeatedly challenge the validity of Goldman's claim that his religious faith required him to cover his head at all times. See infra text accompanying notes 71-74, 124-137. 
Though also absent from the official version of the case, other aspects of the story illustrate the continuous insensitivity Goldman faced from his superiors. For example, amidst the controversy over his yarmulke, while Goldman was conducting a therapy session with eight or ten patients, he was interrupted by a knock on the door. ${ }^{60}$ When he answered, Goldman was told that the base commander wanted to see him regarding the yarmulke. ${ }^{61}$ Goldman sent back a message asking if the commander could wait one hour for the session to end, but the commander insisted that Goldman suspend the session and report immediately to receive an order to remove his yarmulke. ${ }^{62}$

After receiving the order to remove his yarmulke, Goldman requested an urgent meeting with the Vice Wing Commander, who served on the base as Inspector General and ombud. ${ }^{63}$ However, the Inspector General refused to speak with him, responding that Goldman was out of uniform because he was wearing a yarmulke. ${ }^{64}$ Of course, this charge, which originated with the military prosecutor and the base commander, was the matter Goldman wished to discuss. As an alternative, Goldman suggested they meet outdoors where he could cover his head with his military cap. ${ }^{65}$ The Inspector General refused, thus leaving Goldman with no option but to seek the courts' protection. ${ }^{66}$ Accordingly, Goldman filed a motion for a Temporary Restraining Order [TRO] to enjoin the Air Force from enforcing the order that he remove his yarmulke while in uniform. ${ }^{67}$

\section{THE LitiGATION}

Throughout the litigation, Goldman was represented by a team of passionate lawyers led by Nathan Lewin, a prominent advocate of religious rights who took on the case pro bono. ${ }^{68}$ The official story of the litigation captured in the case law provides a notable, often compelling study of varying judicial responses to the Free Exercise arguments asserted by Lewin and the other lawyers on behalf of a member of a religious minority serving in the military. ${ }^{69}$ Yet again, the official story does not convey the extent to which the fate of Goldman's claims turned on personal attitudes often

\footnotetext{
${ }^{60}$ Goldman Interview, supra note 26.

${ }^{61} \mathrm{Id}$.

${ }^{62} \mathrm{Id}$.

${ }^{63} \mathrm{Id}$.

${ }_{65}^{64} I d$.

${ }_{65}^{65} \mathrm{Id}$.

${ }^{66} \mathrm{Id}$.

${ }^{67}$ See Goldman v. Sec'y of Def., 734 F.2d 1531, 1533 (D.C. Cir. 1984).

${ }^{68}$ See http://www.lewinlewin.com/nathan.html

${ }^{69}$ See Goldman v. Weinberger, 475 U.S. 503 (1986); Goldman v. Sec'y of Def., 739 F.2d 657, 658 (D.C. Cir. 1984); Goldman v. Sec'y of Def., 734 F.2d 1531 (D.C. Cir. 1984); Goldman v. Sec'y of Def., 1982 WL 311 (D.D.C. Apr. 26, 1982); Goldman v. Sec'y of Def., 530 F. Supp. 12 (D.D.C. 1981).
} 
influenced by non-legal considerations, some of which directly contradicted important principles in Free Exercise law.

\section{A. The Official Story}

\section{The District Court}

On July 2, 1981, Goldman's motion for a TRO came before Judge Aubrey Robinson, Jr., in the United States District Court for the District of Columbia ${ }^{70}$ Following a hearing, Judge Robinson granted Goldman's motion, and on July 10, he granted Goldman's subsequent motion for a Preliminary Injunction enjoining the Air Force from prohibiting Goldman to wear a yarmulke while in uniform. ${ }^{71}$ In his opinion, Judge Robinson declared unequivocally that "[c]onsistent with the requirements of Orthodox Jewish practice, [Goldman] wears a skull cap, or yarmulke, at all times."72 Accordingly, he forcefully explained, "[t]here can be no doubt the [Goldman's] insistence on wearing a yarmulke is motivated by his religious convictions, and is therefore entitled to First Amendment protections." 73

To be sure, Judge Robinson acknowledged that courts should show a measure of deference to the military's authority for imposing uniformity ${ }^{74}$ Moreover, the opinion quoted extensive sections from an affidavit submitted by Major General Herbert L. Emanuel, "impl[ying] that permitting [Goldman] to wear his yarmulke will crush the spirit of uniformity, which in turn will weaken the will and fighting ability of the Air Force."75 Nevertheless, Judge Robinson ruled in Goldman's favor, deeming the Air Force's allegations "unlikely" and emphasizing that "deference" to the military "cannot and does not permit a court to abdicate its constitutional responsibilities" to protect Free Exercise rights. ${ }^{76}$

The court then conducted a trial on the merits of the case, and on April 26, 1982, Judge Robinson issued a decision. ${ }^{77}$ Again, he stated in no uncertain terms that " $[t]$ he wearing of a yarmulke by a Jewish male is a practice which falls within the ambit of the free exercise clause of the First Amendment to the United States Constitution." 78 The Air Force's position, set forth at trial by Major General William P. Usher, was that "discipline, esprit de corps, motivation, teamwork and image would be injured by allowing a religious exception for the wearing of yarmulkes." ${ }^{\text {"9 }}$ However,

\footnotetext{
${ }^{70}$ See Goldman v. Sec'y of Def., 530 F. Supp. 12 (D.D.C. 1981).

${ }^{71}$ Id. at 17.

${ }^{72}$ Id. at 13.

${ }^{73}$ Id. at 16.

${ }^{74}$ Id. at $15-16$.

${ }^{75}$ Id. At 16.

${ }^{76} \mathrm{Id}$. at 14,16 .

${ }_{78}^{77}$ See Goldman v. Sec'y of Def., 1982 WL 311 (D.D.C. Apr. 26, 1982).

${ }^{78} \mathrm{Id}$. at 3.

${ }^{79} I d$. at 4.
} 
as Judge Robinson observed, these conclusions were not the result of empirical or psychological studies. Instead, he found, they were based on "the personal beliefs and assumptions of Air Force officials" and were therefore "inadequate to withstand constitutional scrutiny." 80 Thus, Judge Robinson permanently enjoined the Air Force from enforcing the order banning Goldman from wearing a yarmulke while in uniform. ${ }^{81}$

\section{The Court of Appeals}

The government appealed Judge Robinson's ruling, and on March 22,1983 , the case was argued in front of the United States Court of Appeals for the District of Columbia Circuit. ${ }^{82}$ The three-judge panel that heard the case consisted of two eminent D.C. Circuit Court Judges, Abner Mikva and Harry Edwards, as well as Judge Luther Swygert, a Senior Judge on the Seventh Circuit Court of Appeals, sitting by designation. ${ }^{83}$ More than one year later, on March 8,1984, the court issued a unanimous decision, in an opinion written by Judge Swygert. ${ }^{84}$ The court's opinion both reversed Judge Robinson's decision and, in some ways, inverted Judge Robinson's conclusions.

Like Judge Robinson, the court rejected the Air Force's assertion that "no free exercise interest is at stake." 85 The Air Force's claim was premised on the assumption that "Jewish law does not require the covering of the head during work," purportedly corroborated by "Goldman's own admission that some Orthodox Jews do not feel obliged to cover their heads at all times." ${ }^{\circ 66}$ As the appeals court explained, this line of reasoning ran afoul of the Supreme Court's rule that "practices based on religious conviction, even if not universally followed, are protected by the free exercise clause." ${ }^{, 7}$ In short, the Court held, "[i]t is undisputable that covering his head is a protected part of Goldman's exercise of his religion., 88

In addition, the court rejected as "unpersuasive" one of the Air Force's ostensible justifications for its inflexible ban on all religious headgear. At trial, General Usher had testified that "an unauthorized hat worn on a flight line might fly into a jet engine and cause it to malfunction and explode." 89 The court responded plainly, "We have no doubt that more narrowly drawn regulations, accommodating religious practices to a greater

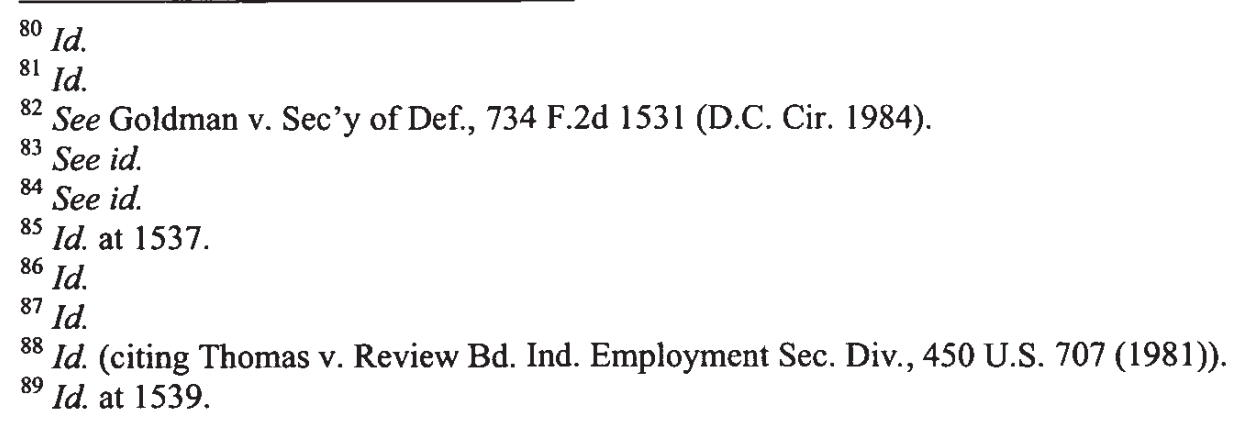


degree, would satisfy such safety concerns. ${ }^{" 90}$ As to any danger allegedly posed by Goldman's yarmulke, the court offered the understated conclusion that "there is no indication that safety within the Mental Health Clinic was threatened." The court likewise characterized as "weak" the Air Force's argument that "it cannot reasonably distinguish among various religious practices" and therefore "must either allow or disallow all requested exceptions." 92

Nevertheless, the court held that "the peculiar nature of the Air Force's interest in uniformity renders the strict enforcement of its regulation permissible." ${ }^{93}$ The court accepted the Air Force's argument that any exceptions for religious practice would "incur[] resentment from those who are compelled to adhere to the rules strictly ...., thereby undermining the goals of teamwork, motivation, discipline, and the like . ..."94 In short, as the court noted, the Air Force "conclude[d] that strict enforcement of its regulations [was] necessary for its military purposes." 95 Unlike Judge Robinson, who insisted that courts have the obligation to consider the plausibility of the military's claim, the Court of Appeals declared nearly categorically that "the Air Force's judgment on this issue is entitled to deference because it is within its expertise and outside ours. ${ }^{966}$

In response to the Court of Appeals' decision, Goldman filed a motion for rehearing en banc. ${ }^{97}$ Although the court denied the motion, ${ }^{98}$ three distinguished judges voted in favor of a rehearing, future Supreme Court Justices Ruth Bader Ginsburg and Antonin Scalia, and Kenneth Starr, future Solicitor General and later Dean of Pepperdine Law School. ${ }^{99}$ Judge Starr filed a powerfully argued and eloquently written opinion dissenting from the court's decision. ${ }^{100}$ The opinion recounted the years of Goldman's distinguished service, during which he "followed uneventfully the dictates of his conscience by wearing the traditional yarmulke, a symbol of his faith whose roots are as deep and venerable as Western civilization itself."101 While acknowledging the military's interest in uniformity, Judge Starr emphasized the significance of the yarmulke as "a symbol of a great faith from which Western morality and the Judeo-Christian tradition have arisen." ${ }^{102}$ In light of the military's insistence on adherence to an

${ }^{90} \mathrm{Id}$.

${ }^{91}$ Id.

${ }^{92}$ Id .

${ }^{93} I d$. at 1540 .

${ }^{94} I d$.

${ }^{95}$ Id.

${ }^{96} \mathrm{Id}$.

${ }^{97}$ See Goldman v. Sec'y of Def., 739 F.2d 657 (D.C. Cir. 1984).

${ }^{98}$ See id.

${ }^{99}$ See id. at 658 (Starr, J., dissenting); id. at 660 (Ginsburg, J., dissenting).

${ }^{100}$ See id. at 658 (Starr, J., dissenting).

${ }^{101} I d$.

${ }^{102} I d$. 
"admittedly arbitrary rule," Judge Starr found the Air Force's treatment of Goldman "patently unconscionable." 103 Thus, he concluded forcefully, the court's holding in the case "does considerable violence to the bulwark of freedoms guaranteed by the Free Exercise Clause."104

Separately, Judge Ginsburg, joined by Judge Scalia, filed a brief dissenting opinion, likewise emphasizing Goldman's years of honorable service and referring to the military's position as "[a]t the least, ... 'callous indifference"" and "counter to 'the best of our traditions' to 'accommodate[] the public service to the[] spiritual needs [of our people]." 105 Thus, she reasoned, the court "should measure the command suddenly and lately championed by the military against the restraint imposed even on an armed forces commander by the Free Exercise Clause of the First Amendment."106

\section{The Supreme Court}

Finally, Goldman appealed the case to the U.S. Supreme Court, which heard oral argument on January $14,1986 .{ }^{107}$ On March 25, 1986, the Court handed down a split decision, which included a majority opinion representing the view of five justices, a concurring opinion of three of those justices, and three separate dissenting opinions issued among the remaining four justices. ${ }^{108}$ Justice Rehnquist, who would soon be elevated to Chief Justice of the U.S. Supreme Court, wrote a relatively brief majority opinion, emphasizing that "[o]ur review of military regulations challenged on First Amendment grounds is far more deferential than constitutional review of similar laws or regulations designed for civilian society." 109 In response to Goldman's assertion that a religious apparel exception would actually increase morale rather than undermine discipline, the Court deferred to the "considered professional judgment" of "the appropriate military officials" regarding the "desirability of dress regulations in the military." 110 Although the Court conceded that not allowing such exceptions would likely render military life more "objectionable" to some religious adherents, the Court ruled that the First Amendment did not require these accommodations. ${ }^{111}$

Justice Stevens' concurring opinion, joined by Justices White and Powell, acknowledged that Goldman "present[ed] an especially attractive

${ }^{103} I d$. at 659 .

${ }^{104} \mathrm{Id}$. at 658 (emphasis in original).

${ }^{105} I d$. at 660 (Ginsburg, J., dissenting) (citing Zorach v. Clauson, 343 U.S. 306 (1952)); $c f$.

Braunfeld v. Braun, 366 U.S. 599, 616 (1961) (Stewart, J., dissenting).

${ }^{106} I d$. at 660 (Ginsburg, J., dissenting) (alterations in original).

107 See Goldman v. Weinberger, 475 U.S. 503 (1986).

${ }^{108}$ See id; id. at 510 (Stevens, J., concurring); id. at 513 (Brennan, J., dissenting); id. at 524 (Blackmun, J., dissenting); id. at 528 (O'Connor, J. dissenting).

${ }^{109}$ Id. at 507.

${ }^{110} \mathrm{ld}$. at 508-09.

${ }^{111} I d$. at 509. 
case for an exception from the uniform regulations." "12 Citing Judge Starr's opinion, Justice Stevens added that the yarmulke "may evoke the deepest respect and admiration - the symbol of a distinguished tradition and an eloquent rebuke to the ugliness of anti-Semitism."113 Nevertheless, Justice Stevens supported the Air Force policy as a method of enforcing uniform treatment of all religions. ${ }^{114}$

Justice Brennan, joined by Justice Marshall, filed a sharply worded and vigorously reasoned dissenting opinion, nearly twice the length of the Court's majority opinion and underlined with a deep sense of empathy for the predicament in which the military had placed Goldman. ${ }^{115}$ The opening lines of Justice Brennan's opinion frame the issue from Goldman's perspective, ${ }^{116}$ describing him as "invok[ing] this Court's protection of his First Amendment right to fulfill one of the traditional religious obligations of a male Orthodox Jew-to cover his head before an omnipresent God."117 In Justice Brennan's view, the Court 'abdicate[d] its role as principal expositor of the Constitution and protector of individual liberties in favor of a credulous deference to unsupported assertions of military necessity."118 Indeed, he accused the Court of "overlook[ing] the sincere and serious nature of [Goldman's] constitutional claim" and "attempt[ing], unsuccessfully, to minimize the burden that was placed on Dr. Goldman's rights." 119 Noting the majority's characterization of the Air Force regulation as merely "objectionable" to Goldman, Justice Brennan emphasized that, in fact, Goldman "was asked to violate the tenets of his faith virtually every minute of every workday." 120

As to the substance of the majority's analysis, Justice Brennan was no less critical, stating that the Court "evade[d] its responsibility by eliminating, in all but name only, judicial review of military regulations that interfere with the fundamental constitutional rights of service personnel."121 In other words, the Court "eschew[ed] its constitutionally mandated role."122 Given the Court's line of reasoning, Justice Brennan inferred, "[i]f a branch of the military declares one of its rules sufficiently important to outweigh a

${ }^{112} I d$. at 510 (Stevens, J., concurring).

${ }^{113}$ Id. (Stevens, J., concurring).

${ }^{114}$ Id. (Stevens, J., concurring).

${ }_{115}^{115}$ See id. at 513 (Brennan, J., dissenting).

${ }^{116}$ See Thomas L. Berg, Minority Religions and the Religion Clauses, 82 WASH. U. L.Q. 919 (2004); Stephen M. Feldman, Religious Minorities and the First Amendment: The History, the Doctrine, and the Future, 6 U. PA. J. CONST. L. 222 (2003); Samuel J. Levine, Toward A Religious Minority Voice: A Look at Free Exercise Law Through a Religious Minority Perspective, 5 Wm. \& Mary Bill Rts. J. 153 (1996).

${ }^{117}$ Goldman, 475 U.S. at 513 (1986) (Brennan, J., dissenting).

${ }^{118} I d$. at 514 (Brennan, J., dissenting).

${ }_{119}^{11} \mathrm{Id}$. (Brennan, J., dissenting).

${ }^{120}$ Id. (Brennan, J., dissenting).

${ }^{121}$ Id. at 515 (Brennan, J., dissenting).

${ }^{122}$ Id. (Brennan, J., dissenting). 
service person's constitutional rights, it seems that the Court will accept that conclusion, no matter how absurd or unsupported it may be.,"123

Addressing the military's claims directly, Justice Brennan barely contained his incredulity, facetiously restating the logic of the military's argument:

[D]iscipline is jeopardized whenever exceptions to military regulations are granted. Service personnel must be trained to obey even the most arbitrary command reflexively. Non-Jewish personnel will perceive the wearing of a yarmulke by an Orthodox Jew as an unauthorized departure from the rules and will begin to question the principle of unswerving obedience. Thus shall our fighting forces slip down the treacherous slope toward unkempt appearance, anarchy, and, ultimately, defeat at the hands of our enemies. ${ }^{124}$

In short, Justice Brennan found that the Air Force's contention "surpasse[d] belief.", 125

Justice Brennan closed his opinion with an eloquent testament to the vital need for the Court to ensure that the military protect the rights of religious minorities:

The military, with its strong ethic of conformity and unquestioning obedience, may be particularly impervious to minority needs and values. A critical function of the Religion Clauses of the First Amendment is to protect the rights of members of minority religions against quiet erosion by majoritarian social institutions that dismiss minority beliefs and practices as unimportant, because unfamiliar. It is the constitutional role of this Court to ensure that this purpose of the First Amendment be realized.

The Court and the military services have presented patriotic Orthodox Jews with a painful dilemma-the choice between fulfilling a religious obligation and serving their country. Should the draft be reinstated, compulsion will replace choice. Although the pain the services inflict on Orthodox Jewish servicemen is clearly the result of insensitivity rather than design, it is unworthy of our military because it is unnecessary. The Court and the military have refused these servicemen their constitutional rights. ${ }^{126}$

\footnotetext{
${ }^{123}$ Id. (Brennan, J., dissenting).

${ }^{124}$ Id. at 516-17 (Brennan, J., dissenting).

${ }^{125} \mathrm{Id}$. at 517 (Brennan, J., dissenting).

${ }^{126} \mathrm{Id}$. at 524 (Brennan, J., dissenting).

Justice Blackmun's dissent struck a similar note:
} 
B. The Unofficial Story

\section{Perspectives of Judge Robinson and Judge Starr}

In addition to Judge Robinson's written opinion, which plainly rejected the military's arguments, the press reports of the courtroom proceedings dramatically illustrate the extent to which Judge Robinson disapproved of the Air Force's claims. ${ }^{127}$ In a sharply worded exchange with Royce C. Lamberth-then Assistant United States Attorney and later Chief Judge of the Court of Appeals for the District of Columbia-Judge Robinson pointedly asked, "Is March Air Force Base going to blow up because this man continues to wear his yarmulke?"128 Lamberth could only reply, "Obviously, the base isn't going to blow up, your honor."129 Judge Robinson continued, "And there aren't going to be any riots, are there?",130 When Lamberth again responded, "No, your honor," Judge Robinson retorted, "Not unless the commanding officer starts them.","131

Similarly, Judge Starr's dissenting opinion takes on even greater significance when viewed in broader context. Although Judge Starr had been on the Court of Appeals for less than one year when Goldman filed his motion for rehearing, he forcefully disagreed with the view of eight of his ten colleagues on the court. ${ }^{132}$ Moreover, unlike Judges Ginsburg and Scalia, who issued a brief dissenting opinion calling on the court to take a closer look at the case, ${ }^{133}$ Judge Starr wrote a stirring and powerful critique of the decision rendered just months earlier by two of his most distinguished

If the Free Exercise Clause of the First Amendment means anything, it must mean that an individual's desire to follow his or her faith is not simply another personal preference, to be accommodated by government when convenience allows. Nor may free exercise rights be compromised simply because the military says they must be. The Air Force has failed to produce even a minimally credible explanation for its refusal to allow Goldman to keep his head covered indoors. I agree with the Court that deference is due the considered judgment of military professionals that, as a general matter, standardized dress serves to promote discipline and esprit de corps. But Goldman's modest supplement to the Air Force uniform clearly poses by itself no threat to the Nation's military readiness.

Id. at 525 (Blackmun, J., dissenting).

${ }^{127}$ See AP REPORT, July 11, 1981 (on file with author).

${ }^{128} \mathrm{Id}$.

${ }^{129} \mathrm{Id}$.

${ }^{130} \mathrm{Id}$.

${ }^{131} I d$.

${ }^{132}$ See Goldman v. Sec'y of Def., 739 F.2d 657, 658 (D.C. Cir. 1984) (Starr, J., dissenting).

${ }^{133}$ See id. at 660 (Ginsburg, J., dissenting). 
colleagues, Judges Mikva and Edwards. ${ }^{134}$ Indeed, responding to the tone and language employed by Judge Starr, one Justice Department official dismissed the opinion as an "emotional rant."135 In contrast, Dean Starr views his opinion as an expression of his strongly held position that the Free Exercise Clause requires the government to accommodate religion. ${ }^{136}$ In addition, he sees his willingness to disagree with his colleagues on the court as reflecting his understanding of the judge's duty to exercise independent judgment on cases and controversies. ${ }^{137}$

\section{The Government's Strategy}

Throughout the litigation, the government repeatedly questioned whether Goldman's wearing a yarmulke qualified as a constitutionally protected religious exercise. In a deposition before the trial, an opposing lawyer asked Goldman about the fact that Nathan Lewin, who was representing Goldman in the case, observed Jewish religious practice but was not wearing a yarmulke. ${ }^{138}$ Goldman responded that some devout Orthodox Jewish individuals do not wear yarmulkes when engaged in their professional work. ${ }^{139}$ The question aimed to imply that if another Orthodox Jewish individual did not wear a yarmulke at all times, then Goldman could not have a religious obligation to wear a yarmulke while in uniform. However, as the Court of Appeals later emphasized, Supreme Court doctrine adopts the religious understanding and practices asserted by the plaintiff, not those adopted by other members of the plaintiff's religious community. ${ }^{140}$

Nevertheless, the Court of Appeals ruled in favor of the Air Force, surprising even the Justice Department's lawyer, who had wondered aloud whether it was worthwhile arguing the military's appeal before a panel that consisted of such liberal judges as Abner Mikva and Harry Edwards. ${ }^{141}$ Indeed, Judge Mikva later remarked to Judge Starr that the judicial views expressed in the Goldman case demonstrate that judges should not be pigeonholed. ${ }^{142}$ Years later, Lewin asked Mikva about the basis for the court's unexpected decision. ${ }^{143}$ Mikva recalled that because he was Jewish, following oral argument the other two judges asked for his estimation of the

\footnotetext{
${ }_{134}^{134}$ See Goldman v. Sec'y of Def., 734 F.2d 1531 (D.C. Cir. 1984).

135 Author's Interview with Kenneth Starr, Dean, Pepperdine Law School, Malibu, California, June 13, 2008 [hereinafter Starr Interview].

${ }_{136}^{136}$ d.

${ }^{137} \mathrm{Id}$.

${ }^{138}$ Goldman Interview, supra note 26.

${ }^{139} \mathrm{Id}$.

${ }^{140}$ Goldman v. Sec'y of Def., 734 F.2d 1531, 1537 n.8 (D.C. Cir. 1984). See supra note 45.

${ }_{141}$ Author's Telephone Interview with Nathan Lewin, Partner, Lewin \& Lewin, LLP, Los Angeles, California to Washington, D.C., Sept. 23, 2008 [hereinafter Lewin Interview].

${ }^{142}$ Starr Interview, supra note 135.

${ }^{143}$ Lewin Interview, supra note 141.
} 
religious significance of wearing a yarmulke. ${ }^{144}$ Mikva responded that the yarmulke was "not that important," thus contributing to an attitude among the panel that minimized the value of Goldman's religious claim. ${ }^{145}$

When the case reached the Supreme Court, the government continued to maintain the position that Goldman was not engaging in a required religious practice under Jewish law. In its brief to the Supreme Court, the government referred to the wearing of a yarmulke as "a custom followed by some, but not all, devout Orthodox Jewish males ...."146 In a footnote, the government further asserted that "[a]lthough [Goldman's] brief suggests that the wearing of a yarmulke is required by Jewish law, . . . authorities introduced in the district court clearly demonstrate otherwise." 147 It seems odd for the government to make such a strong statement regarding a matter of complex religious interpretation, contradicting the religious interpretation offered by Goldman, who is a rabbi. Moreover, the government's argument again betrayed a disregard for a basic element of free exercise jurisprudence, which requires that the court accept the plaintiff's understanding of religious practice. ${ }^{148}$

Indeed, the government's line of reasoning proved to be of considerable concern for at least one of the justices. At the very start of her oral argument before the Supreme Court, Kathryn Oberly, the Assistant Solicitor General, was interrupted with the direct question, "Are you still adhering to footnote four?"149 Oberly responded, "As to whether the yarmulke is required? Yes, it's our position ... that although it is a strong, well-established practice and tradition of devout Orthodox Jewish males to wear a yarmulke, it is not a requirement of Jewish law."150 Although Oberly also acknowledged that Goldman's "interpretation of what he should do as a devout Orthodox Jew is wear a yarmulke, and we are willing to accept that as a sincere religious belief on his part," she nevertheless insisted that "it's not at all irrelevant for the Court to take cognizance of the fact that . . . it's not required by the laws of his religion and ... Jewish rabbinical authorities agree with that." 151

Although the Supreme Court's majority opinion does not reference this exchange, the opinion is noticeably silent regarding the religious significance of the yarmulke. As Justice Brennan observed, the opinion characterized the prohibition on wearing a yarmulke as merely

\footnotetext{
${ }^{144} I d$.

${ }^{145} \mathrm{Id}$.

${ }^{146}$ BRIEF FOR RESPONDENTS at 12, Goldman v. Weinberger, 475 U.S. 503 (1986) (No. 841097).

${ }^{147}$ Id. at 6 \& n. 4.

148 See supra note 45.

149 TRANSCRIPT OF ORAL ARGUMENT at 24-25, Goldman v. Weinberger, 475 U.S. 503 (1986)

(No. 84-1097).

${ }^{150} \mathrm{Id}$. at 25.

${ }^{151}$ Id. at 26.
} 
“objectionable" for Goldman. ${ }^{152}$ In contrast, Justice Brennan's dissenting opinion opened with an unequivocal reference to Goldman's "First Amendment right to fulfill one of the traditional religious obligations of a male Othodox Jew-to cover his head before an omnipresent God." Indeed, Justice Brennan accused the majority of "attempt[ing], unsuccessfully, to minimize the burden that was placed on Dr. Goldman's rights." As As Justice Brennan explained, the Air Force's policy "sets up an almost absolute bar to the fulfillment of a religious duty[,]" requiring that Goldman "violate the tenets of his faith virtually every minute of every workday." 155

\section{CONCLUSION: LOOKING BACK AT THE CASE-Questions THAT REMAIN}

In retrospect, it remains somewhat difficult to understand the attitudes motivating the military, the government lawyers, and the courts that ruled against Goldman. In fact, the legal effect of the Supreme Court's decision in the Goldman case was short-lived, as Congress soon enacted legislation accommodating unobtrusive religious apparel in the military. ${ }^{156}$

From the outset of the case, the dispute surprised Goldman, who had worn his yarmulke through years of distinguished military service, without incident. Although the base commander supported the prosecutor's complaint and ordered Goldman not to wear his yarmulke while in uniform, Lewin thought the order represented an outlandish policy issued by a single commander, and he approached the general counsel at the Pentagon to try to settle the matter. ${ }^{157}$ Lewin was surprised, however, that the Department of Defense did not agree with his assessment and instead decided to litigate the case. ${ }^{158}$ When Judge Robinson ruled in favor of Goldman, expressing similar outrage toward the base commander, Lewin expected the government to concede, and he was further surprised when the government appealed the decision. ${ }^{159}$

Likewise, Goldman remains both puzzled and upset by the military's focus on his minor and seemingly inconsequential departure from uniform, given the prominent and sometimes routine acceptance of more significant violations of standards governing military uniforms and procedure. $^{160}$ In one particularly egregious example, just months after

${ }^{152}$ Goldman v. Weinberger, 475 U.S. 503, 514 (1986) (Brennan, J., dissenting).

${ }^{153}$ Id. at 513 (Brennan, J., dissenting).

${ }^{154} \mathrm{Id}$. at 514 (Brennan, J., dissenting).

${ }^{155}$ Id. (Brennan, J., dissenting).

${ }^{156}$ See 10 U.S.C. $\$ 774$. See generally Dwight Sullivan, The Congressional Response to Goldman v. Weinberger, 121 MIL. L. REV. 125 (1988).

${ }^{157}$ Lewin Interview, supra note 141.

${ }^{158}$ Id.

${ }^{159} \mathrm{Id}$.

${ }^{160}$ Goldman Interview, supra note 26.

Untold Stories of Goldman v. Weinberger 223 
Goldman was ordered not to wear his yarmulke while in uniformostensibly because it detracted from the sense of discipline and uniformity in the Air Force-the entire front page of The Beacon, the unofficial newspaper at March Air Force base, was dedicated to the story headlined: "BUSY BREWER team smashes on-time record."161 The story boasted of the success of B-52 Bomber aircrews from March, who flew NATO exercises from a base in the United Kingdom, under conditions that "closely simulated a war-time deployed detachment." 162 Among other details of the mission, the article recounted that " $[t]$ he crew chiefs were led by MSgt. Walter Monk, who's [sic] lucky green and white garter adorned his left arm for every launch." ${ }^{\prime 63}$

To this day, Goldman continues to ask the obvious questions: Why was the Air Force so opposed to his wearing a yarmulke? ${ }^{164}$ Why was the government so focused on Goldman's case, to the extent that it litigated the matter all the way to the United States Supreme Court? $?^{165}$ Finally, how could the Air Force justify permitting the crew chief of a major NATO exercise, flying B-52 bombers over Europe, to wear a flamboyant green and white garter as a sign of luck, while refusing to allow Goldman to wear a yarmulke, an expression of religious modesty and commitment, while serving as clinical psychologist at a military hospital in California? ${ }^{166}$ While these questions may defy simple answers, they warrant careful reflection, not only because of their historical significance, but also because of the lessons they may provide for current and continuing issues of religious accommodation in the military.

${ }^{161}$ See Busy Brewer: Team Smashes On-Time Record, THE BEACON, Oct. 16, 1981, at 1(on file with author).

${ }^{162} I d$. at 6.

${ }^{163} \mathrm{Id}$.

${ }^{164}$ Goldman Interview, supra note 26.

${ }^{165} \mathrm{Id}$.

${ }^{166} \mathrm{Id}$. 